\title{
Modelling Suitable Habitat and Ecological Characteristics of Old Trees Using DIVA-GIS in Anhui Province, China
}

\author{
Chunping Xie ${ }^{1,3 *}$, Xiaoya Yu ${ }^{2}$, Dawei Liu ${ }^{1,3}$, Yan Fang ${ }^{1,3}$ \\ ${ }^{1}$ Institute of Criminal Science and Technology, Nanjing Forest Police College, Nanjing, China \\ ${ }^{2}$ School of Tourism and Resource Environment, Qiannan Normal University for Nationalities, Duyun, Guizhou, China \\ ${ }^{3}$ Key Laboratory of State Forest and Grassland Administration on Wildlife Evidence Technology, Nanjing, China
}

Received: 2 May 2019

Accepted: 27 June 2019

\begin{abstract}
Old trees as a natural heritage are significant components of terrestrial biodiversity, and they also play an important role in the ecosystem. An overall understanding of the distribution patterns and ecological characteristics of old trees in China's Anhui Province will provide valuable insights into old tree conservation and scientific planning. Based on the data from 617 field collection and historical sample documents, we applied DIVA-GIS combined with the BIOCLIM model to qualitatively and quantitatively analyse the distribution patterns of old trees and their dominant climate factors for the first time. The model assessment results indicated that the area under the receiving operator curve (AUC) and kappa statistics reached 0.969 and 0.921 , respectively, which indicated that the data fit the model very well and that the prediction was highly reliable. According to principal component analysis (PCA), the main bioclimatic variables influencing the distribution of old trees were as follows: water requirements, drought tolerance, preference temperature, heat resistance, cold tolerance and others. The cumulative frequency curves further confirmed that the ecological characteristics of the geographical distributing area for old trees in the study area were annual mean temperature $\left(10.90 \sim 16.30^{\circ} \mathrm{C}\right)$, maximum temperature of warmest month $\left(25.60 \sim 32.40^{\circ} \mathrm{C}\right)$, mean temperature of coldest quarter $\left(0.30 \sim 4.90^{\circ} \mathrm{C}\right)$, annual precipitation $(665.00 \sim 1701.00 \mathrm{~mm})$, precipitation of driest month $(14.00 \sim 47.00 \mathrm{~mm})$ and precipitation of driest quarter $(45.00 \sim 173.00 \mathrm{~mm})$. The current distribution pattern of old trees was mainly affected by precipitation factors. Furthermore, this study demonstrates a new method for the conservation of old trees by virtue of GIS software and predictive models. All of these results could help establish conservation plans for old trees.
\end{abstract}

Keywords: old trees, suitable habitat, BIOCLIM, DIVA-GIS, bioclimatic variables

*e-mail: ascendens@qq.com 


\section{Introduction}

Old trees (also called large old trees, heritage trees, veteran trees, etc.) play a critical role in ecosystems globally [1-3]. Due to the old trees' properties of environmental improvement, aesthetic enhancement, cultural value, ecological and biodiversity enrichment, and economic, social and health benefits [1, 4], they have been a focus of human beings for a long time throughout the world [5]. Old trees are also valuable cultural resources and important historical relics. Old trees not only record the natural conditions of a region's climate, hydrology, geology, geography, vegetation, and ecology, but also reflect the history of human activities and social development in the region. Old trees overcome spatial and temporal limitations, and they are the envoy connecting history, nature and human beings. Thus, old trees are non-renewable natural and cultural heritage resources with extremely high conservation value [6]. However, old trees have to struggle to survive because of the rapid changes in the global climate and other factors [7-9]. Populations of large old trees are rapidly declining in many parts of the world, which has serious implications for ecosystem integrity and biodiversity $[10,11]$. Therefore, creating more effective strategies for the conservation of old trees should be addressed urgently.

For various reasons, the number of old trees had decreased drastically, and they have suffered losses for a long time [12]. The administrative department and experts are aware of the seriousness of the problem in China. Hence, since as early as the 1980s, various levels of Chinese governments have carried out the conservation of old trees [13]. Particularly in September 2001, the National Afforestation Environmental Protection Commission and State Forestry Administration launched a nationwide census of famous and old trees. At the same time, many related studies on old trees had been continually developed, mainly focusing on the diversity of old trees in special regions $[14,15]$, assessment of the growth status $[12,16]$, rejuvenation technology $[17,18]$, spatial distribution $[3$, $13]$, evaluation of tree age $[19,20]$, monetary valuation $[21,22]$ and so on. Such studies in recent years have promoted the theory and methods related to the conservation of old trees.

With the development of GIS technology and computer technology, geographic information systems (GIS) have been successfully applied for the conservation of old trees. For instance, GIS data on ancient and famous trees in the Sun Yat-sen Mausoleum provided information on ancient and famous trees for management, monitoring, rational utility and correlative research [23]. Based on the integrated techniques of virtual plants and GIS, a three-dimensional management information system of ancient and famous trees was realized, which promoted management and protection from the aspects of standardization, informalization and visualization [24]. A new mobile application was developed for conservation by virtue of the enterprise J2EE platform and GIS, which provided an efficient and quick tool for protection [25]. In Dongguan, Guangdong Province, the established system based on GIS offered a digital management platform for the management and protection of old and famous trees via information reporting, information sharing, and management decision-making [26]. Similar studies were also carried out in many administrative regions of China [15, 27, 28]. Although many of the studies mentioned above have been performed, the study of old trees based on GIS is still far from sufficient, particularly the in-depth study of the geographical distribution of old trees.

Species distribution models (SDMs) based on climatic variables have become a popular topic in the field of ecology [29, 30], and SDMs have been widely applied in many fields of interest, such as biodiversity discovery, phylogeography, species invasions, climate change effects on species distribution, conservation planning and species management [29, 31-38]. With the availability of high-resolution interpolated climate data for global land areas and continuously updated algorithms, SDMs are emerging as an important tool in ecological research [39-41]. Bioclimatic variable (BIOCLIM), Domain (DOMAIN), generalized linear models (GLMs), multivariate adaptive regression splines (MARS), genetic algorithm for rule-set production (GARP), maximum entropy modelling (Maxent) and boosted regression trees (BRT) are currently some of the most popular and commonly used SDMs [34]. Many software programs can help to operate complex SDMs, such as R, Maxent, MATLAB, CANOCO, DIVA-GIS, Biomapper, and openModeller [42], which each have their own strengths and weaknesses.

In this paper we will apply DIVA-GIS 7.5 software with the BIOCLIM model to analyse the distribution patterns of old trees in Anhui Province. DIVA-GIS, which was developed as a joint project by several institutions (International Potato Center, FAO, Museum of Vertebrate Zoology, etc.), is a free GIS software program used for the analysis of geographical data [43-49], and the data are processed into standard GIS formats that can be applied to other general software. BIOCLIM was the first SDM program in widespread use [50]. BIOCLIM can be applied to conservation biogeography, such as quantifying the environmental niche of a species, identifying areas where a species might be invasive, assisting conservation planning and assessing the likely impacts of climate change on species distributions [29].

Traditional conservation methods for old trees have been unable to meet the need for development. However, based on the DIVA-GIS platform, the climatic data of geographical distribution points can be obtained effectively, and the BIOCLIM model can be used to predict the suitable habitat of old trees. The relationship between the geographical distribution pattern and bioclimatic factors can be explained by GIS technology, which provides a scientific basis for the conservation 
of old tree resources in the future. The purpose of the study is to (1) disclose the distribution pattern of old trees in Anhui Province, (2) find the main climatic factor that determines the distribution pattern, and (3) model the suitable habitat of old trees in the study area. The findings can instantly inform management decisions for old trees in Anhui Province.

\section{Materials and Methods}

\section{Study Area}

Anhui Province in the People's Republic of China is located in the eastern region of the country with complex topography. It is approximately $570 \mathrm{~km}$ from south to north and $450 \mathrm{~km}$ from east to west, which covers an area of $140.1 \times 103 \mathrm{~km}^{2}$. Two of the most important rivers in China, the Yangtze River and the Huaihe River, flow eastward across the south and north of the province, respectively, dividing its area into three natural regions: the region to the north of the Huaihe is a vast expanse of flatland plain with loamy soil; the region between the Huaihe and the Yangtze is hilly terrain with a network of criss-crossing rivers and a random distribution of terraces; the region to the south of the Yangtze is a mountainous area that includes Mt. Huangshan and Mt. Jiuhua. Located in the transition region of the warmtemperate zone and subtropical zone, the climate of Anhui is warm and humid with distinctive seasons. The climate in the area north of the Huaihe River is a warmtemperate semi-humid monsoon climate; the area south of the Huaihe is a subtropical humid monsoon climate. The province's annual rainfall differs greatly, and its weather is very dynamic, with frequent spring droughts and summer floods; the average annual precipitation is 800 to $1,800 \mathrm{~mm}$ (31 to 71 inches). The average annual temperature ranges from $14^{\circ} \mathrm{C}$ to $17^{\circ} \mathrm{C}$. The sun shines an average of 1,800 to 2,500 hours per year. Anhui Province has 200 to 250 frost-free days, and throughout the year the province has distinct seasons, abundant precipitation, and a pleasant climate.

\section{Bioclimatic Variables and Old Tree Data}

Nineteen bioclimatic variables with $2.5^{\prime}$ (ca. $5 \mathrm{~km}$ ) spatial resolution are available from DIVA-GIS (http:// www.diva-gis.org/climate.htm) $[43,51]$, which is used to determine the most influential variables associated with old tree distribution in Anhui Province. The bioclimatic variables represent annual trends, seasonality and extreme or limiting environmental factors. The variables are coded as follows: annual mean temperature (Bio $1,{ }^{\circ} \mathrm{C}$ ), mean diurnal range (Bio $2,{ }^{\circ} \mathrm{C}$ ), isothermality (Bio2/Bio7) $(\times 100)$ (Bio 3), temperature seasonality (standard deviation *100) (Bio 4, Coeff. of variation), maximum temperature of warmest month (Bio $5,{ }^{\circ} \mathrm{C}$ ), minimum temperature of coldest month (Bio 6, ${ }^{\circ} \mathrm{C}$ ), temperature annual range $\left(\mathrm{Bio} 7,{ }^{\circ} \mathrm{C}\right)$, mean temperature of wettest quarter (Bio $8,{ }^{\circ} \mathrm{C}$ ), mean temperature of driest quarter (Bio 9, ${ }^{\circ} \mathrm{C}$ ), mean temperature of warmest quarter (Bio $10,{ }^{\circ} \mathrm{C}$ ), mean temperature of coldest quarter (Bio 11, ${ }^{\circ} \mathrm{C}$ ), annual precipitation (Bio 12, mm), precipitation of wettest month (Bio 13, mm), precipitation of driest month (Bio 14, $\mathrm{mm}$ ), precipitation seasonality (coefficient of variation) (Bio 15, Coeff. of variation), precipitation of wettest quarter (Bio 16, mm), precipitation of driest quarter (Bio 17, $\mathrm{mm}$ ), precipitation of warmest quarter (Bio 18, $\mathrm{mm}$ ) and precipitation of coldest quarter (Bio19, mm).

One of the most important processes for the conservation of old trees is how to define an old tree. Some scholars believe that an old tree should be defined according to its relative size (diameter and height) and on a species-specific basis rather than depending on its real age [52]. This method has been applied in Romania [1, 53], Brazil [54], Hong Kong, China [4], etc. However, according to the regulation of 'Technical regulation for surveying of old and notable trees' (promulgated by the State Forest Administration of P. R. C. in 2016), old trees were defined as trees aged greater than or equal to 100 years; at the same time, the old trees were divided into three protection classes: first-class $\geq 500$ years, $300 \leq$ second-class $\leq 499$ years and 100 years $\leq$ third-class $\leq 299$ years. Because data on old tree age were mostly evaluated by local experts, most of the data had some errors. Therefore, it is very difficult to precisely measure the age of old trees. Thus, to ensure the representation of data, we selected trees older than 500 years as determined by local forestry experts as study objects.

We gathered the data of old trees in the following ways: (1) online search of scientific literature from the China National Knowledge Infrastructure (www. cnki.net) and local government websites, (2) review of documents from the forestry bureaus of cities or counties, and (3) field investigations by authors from 2015 to 2019 aperiodicaly. A total of 617 occurrences were obtained, belonging to 62 species, 52 genera and 30 families.

When the locations of old trees were recorded we used GIS software (LocaSpace Viewer version 3.7) to obtain the coordinates.

\section{Data Analysis}

The data of old trees gathered in the study area were evaluated for distribution pattern, suitable habitat and ecological characteristics. For principal component analyses (PCA), 19 bioclimatic variables were standardized to a mean of 0 and standard deviation of 1 ; data transformation was performed by PAST 3.23 [55]. Geographic base maps of Anhui Province (.shp format) were downloaded from the National Platform for Common Geospatial Information Services (http://www. tianditu.gov.cn/). In this study, the BIOCLIM model was used to: (a) describe the environment in which the old trees had been recorded and (b) predict other locations 
that may be suitable for the old trees to currently reside. Simultaneously, $75 \%$ of distribution data on old trees was applied for training, and the remaining was applied for testing, repeating 99 times; the result was saved as an output file in .grd format. Next, a stack data set was created to build the area under the receiving operator curve (ROC) (AUC). The AUC was used to evaluate the model's goodness-of-fit, and the model with the highest AUC value was considered the best performer. The AUC was used as the BIOCLIM predictive performance metric. The AUC has an important statistical property: the AUC of a classifier is equivalent to the probability that the classifier will rank a randomly chosen positive instance higher than a randomly chosen negative instance [56]. The AUC is an effective thresholdindependent index that can evaluate a model's ability to discriminate presence from absence [37]. In general, the AUC is between 0.5 and 1 . AUC $<0.5$ describes models that perform worse than chance and rarely occur in reality. An AUC of 0.5 represents pure guessing. Model performance is categorized as failing (0.5-0.6), poor (0.6-0.7), fair (0.7-0.8), good (0.8-0.9), or excellent (0.9-1) [57]. The other prediction accuracy index, kappa, was also applied. The kappa statistic ranges from -1 to +1 , where +1 indicates perfect agreement and values of zero or less indicate a performance no better than random [58]. The above calculation process was performed using DIVA-GIS 7.5 software.

\section{Results}

\section{Distribution Pattern of Class I Old Trees in Anhui Province}

The distribution pattern of old trees in Anhui Province had the following characteristics (Fig. 1): (1) the centres of the distribution areas for old trees were in the southern and southwestern parts of the province. The density of old trees in these two regions was significantly higher than that in other locations. (2) The distribution of old trees tended to decrease with increasing latitude; in particular, the number of individuals of old trees was gradually reduced to the north of the Huaihe River. (3) Along both the Yangtze and Huaihe Rivers, the number of old trees was lower than that in other areas. (4) There were few old trees recorded in the central part of Anhui Province.

The current distribution pattern of old trees in the study area was closely related to the topography, agriculture, economic and social development of Anhui Province. First, the northern part of Anhui Province was a traditional farming area, and its terrain was mainly plain, and the plain is mainly located in Huaibei plain. Because of the thousands of years of an agricultural economy, there was no natural forest in this region, which resulted in low diversity of plant species. Populus spp., Salix spp., Ulmus spp. and Sophora spp. were very

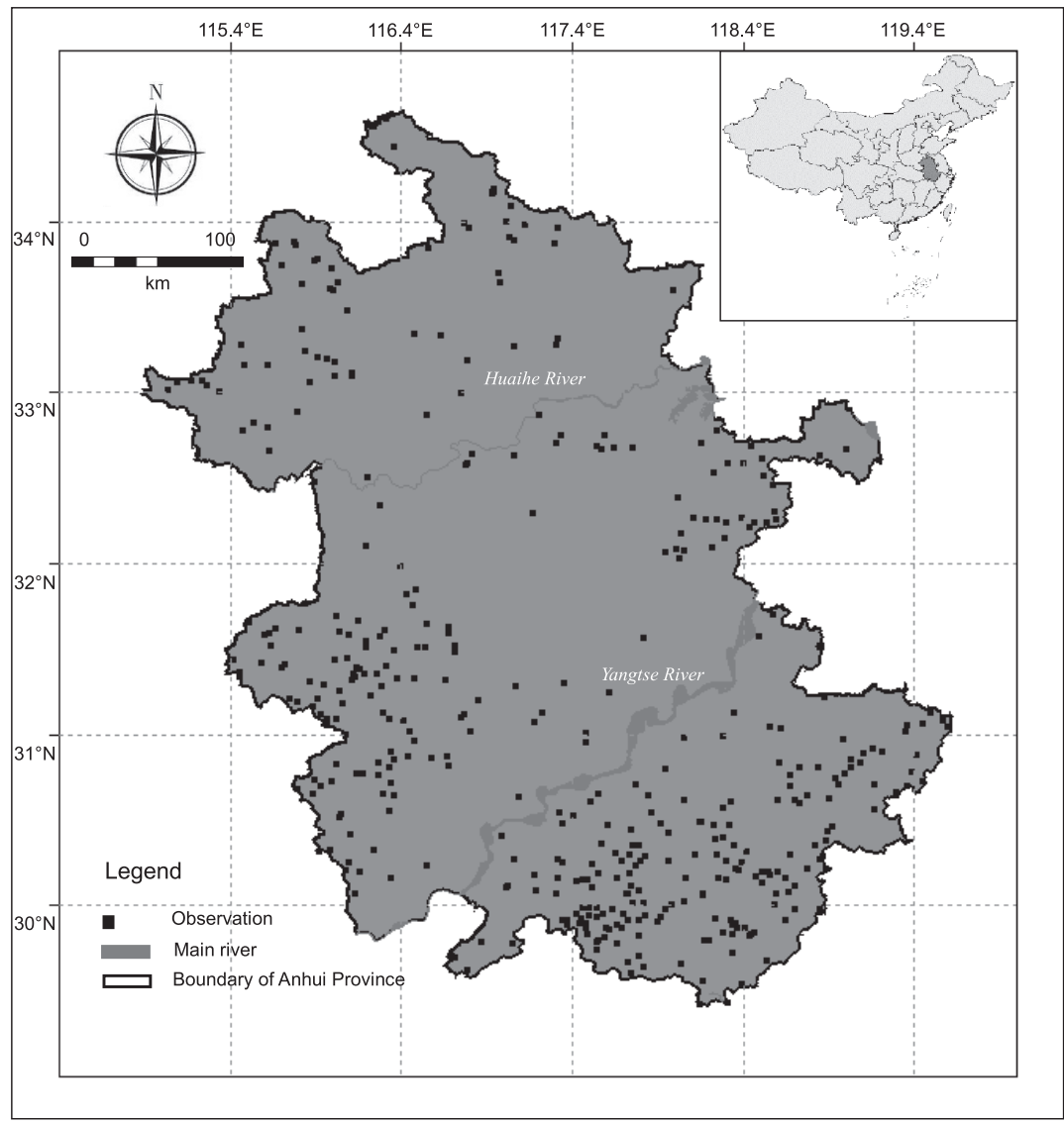

Fig. 1. Distribution pattern of old trees in Anhui Province. 
Table 1. Climatic factor loadings for principal component analysis (PCA).

\begin{tabular}{|c|c|c|c|c|c|c|c|}
\hline Principal component & PC1 & $\mathrm{PC} 2$ & PC3 & PC4 & PC5 & PC6 & PC7 \\
\hline Eigenvalue & 12.48 & 4.21 & 0.86 & 0.68 & 0.41 & 0.16 & 0.09 \\
\hline Contribution rate & 65.70 & 22.17 & 4.52 & 3.58 & 2.14 & 0.82 & 0.45 \\
\hline \multirow[t]{2}{*}{ Cumulative contribution rate } & 65.70 & 87.87 & 92.39 & 95.97 & 98.12 & 98.94 & 99.39 \\
\hline & \multicolumn{7}{|c|}{ Factor loadings } \\
\hline Bio1 & -0.03 & 0.48 & 0.16 & 0.04 & -0.13 & 0.00 & 0.00 \\
\hline Bio2 & -0.26 & -0.04 & 0.24 & 0.33 & 0.13 & 0.24 & -0.04 \\
\hline Bio3 & -0.22 & -0.10 & 0.28 & 0.61 & 0.15 & 0.11 & -0.21 \\
\hline Bio4 & -0.27 & 0.07 & 0.04 & -0.29 & -0.03 & 0.11 & 0.26 \\
\hline Bio5 & -0.14 & 0.42 & 0.12 & 0.07 & -0.07 & 0.15 & 0.20 \\
\hline Bio6 & 0.20 & 0.33 & -0.05 & 0.10 & -0.15 & -0.28 & -0.04 \\
\hline Bio7 & -0.28 & 0.05 & 0.14 & -0.03 & 0.07 & 0.35 & 0.19 \\
\hline Bio8 & -0.25 & -0.01 & -0.36 & 0.31 & 0.05 & -0.18 & 0.65 \\
\hline Bio9 & 0.14 & 0.30 & -0.14 & -0.06 & 0.91 & -0.08 & -0.03 \\
\hline Bio10 & -0.16 & 0.40 & 0.10 & -0.05 & -0.11 & -0.01 & 0.09 \\
\hline Bio11 & 0.14 & 0.41 & 0.06 & 0.24 & -0.13 & -0.18 & -0.16 \\
\hline Bio12 & 0.28 & -0.04 & 0.11 & 0.14 & -0.04 & 0.05 & 0.07 \\
\hline Bio13 & 0.24 & -0.07 & 0.49 & -0.15 & 0.02 & -0.21 & 0.27 \\
\hline Bio14 & 0.28 & 0.04 & -0.01 & -0.08 & -0.04 & 0.33 & 0.27 \\
\hline Bio15 & -0.23 & -0.08 & 0.49 & -0.29 & 0.17 & -0.28 & 0.13 \\
\hline Bio16 & 0.26 & -0.05 & 0.35 & 0.10 & 0.02 & 0.03 & 0.05 \\
\hline Bio17 & 0.28 & 0.02 & -0.07 & 0.07 & -0.03 & 0.33 & 0.18 \\
\hline Bio18 & 0.24 & -0.18 & 0.07 & 0.34 & 0.03 & -0.27 & 0.38 \\
\hline Bio19 & 0.27 & 0.04 & 0.08 & -0.04 & 0.10 & 0.46 & 0.06 \\
\hline
\end{tabular}

common in this area; however, it was very difficult for these kinds of species to survive for hundreds of years, particularly poplar and willow. The central part of Anhui Province included Hefei, Wuhu, Bengbu and Chuzhou cities, which was the most economically developed area in Anhui Province with strong urbanization. However, it was also a dense zone of rivers and lakes, mainly including Chaohu, Shijiu and Nanyihu lakes. Therefore, almost no old trees were found in this area. Xuancheng, Huangshan, Lu'an and Anqing cities are located in the southwestern and southern regions of the province. This region is a typical hilly and mountainous region that incorporates a series of complex topographies, such as middle mountains, low mountains, hills, and tablelands. At the same time, this area was rich in various rare or endangered plant resources, such as Taxus wallichiana var. chinensis, Podocarpus macrophyllus, Ginkgo biloba, and Pteroceltis tatarinowii. Hence, this area could provide an enormous benefit for the breeding of old trees. Along the Yangtze and Huaihe, there were few individuals of old trees found because of the landform and strong human activities.

\section{Analysis of Main Climatic Factors}

A matrix of 19 bioclimatic variables and 617 individuals of old trees was built for principal component analysis. The results indicated that nearly all of the vital bioclimatic information on the distribution pattern was contained in the first two principal components, which explained $87.87 \%$ of the variation (Table 1 and Fig. 2). The first principal components explained $65.70 \%$ of the variation, and the main bioclimatic factor with high loading values included annual precipitation (Bio 12, 0.28), precipitation of driest month (Bio 14, 0.28), precipitation of driest quarter (Bio 17, 0.28) and precipitation of coldest quarter (Bio19, 0.27). The above four bioclimatic factors were closely related to precipitation; for this reason, precipitation was of the greatest significance for the distribution of old trees. The second principal component explained $22.17 \%$ of the variation; however, the annual mean temperature (Bio1, 0.48), maximum temperature of the warmest month (Bio 5, 0.42), mean temperature of the warmest quarter (Bio 10, 0.40), and mean temperature of the 


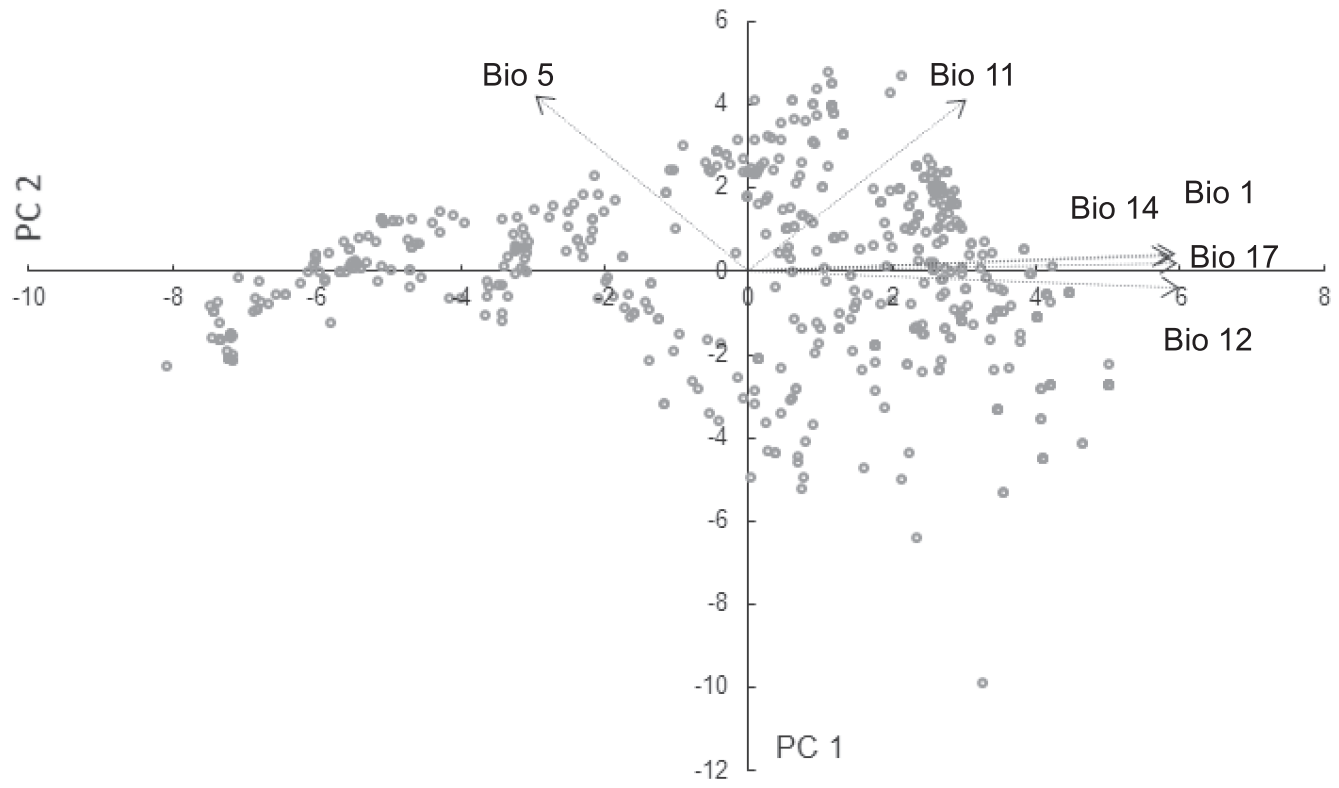

Fig. 2. Principal component analysis of 19 bioclimatic variables.

coldest quarter (Bio 11, 0.41) were useful variables for explaining the distribution of the old trees; these variables were relevant to temperature. From the third principal components to the end, the contribution rate degraded gradually, which explained only $12.13 \%$ of the total variation.

In light of the implications of the different bioclimatic variables, they could be defined as water requirements (Bio12), drought tolerance (Bio 14 and Bio 17), preference temperature (Bio 1), heat resistance (Bio 5) and cold tolerance (Bio 11). Therefore, according to principal component analysis (Table 1 and Fig. 2), the distribution pattern of old trees was affected by water requirements $>$ drought tolerance $>$ preference temperature $>$ heat resistance $>$ cold tolerance $>$ other bioclimatic variables.

Based on the rank of the factor loadings, six dominant climatic factors were selected for variable statistics after PCA screening (Table 2 and Fig. 3). Many studies considered that a habitat was suitable for old trees when the continuous range of cumulative frequency was $\geq 90 \% \quad[47,59,60]$. The results indicated that the suitable bioclimatic ranges of Bio 1, Bio 5, Bio 11, Bio 12, Bio 14 and Bio 17 were $10.90 \sim 16.30^{\circ} \mathrm{C}$, $25.60 \sim 32.40^{\circ} \mathrm{C}, \quad 0.30 \sim 4.90^{\circ} \mathrm{C}, \quad 665.00 \sim 1701.00 \mathrm{~mm}$, $14.00 \sim 47.00 \mathrm{~mm}$ and $45.00 \sim 173.00 \mathrm{~mm}$, respectively (Table 2).

\section{Modelling of Suitable Habitat}

In accordance with the result of the prediction by the BIOCLIM model, the suitable habitat for old trees in Anhui Province can be divided into six levels as follows: not suitable (0), low (0-2.5\%), medium (2.5\%-5.5\%), high (5\%-10\%), very high $(10 \%-20 \%)$ and excellent (20\%-46\%) (Fig. 4). Under the current climate conditions, there was a high ratio of suitable areas for old trees to the south of the Huaihe and Yangtze rivers (excluding the areas alongside the Yangtze and southwest of Anqing city). Second, the southeast was also an area suitable for old trees, especially in Xuancheng city. With increasing latitude, the northern part of Anhui Province was not an agreeable climatic environment for old trees, such as Suzhou, Huaibei, Bozhou and

Table 2. Variable statistics of six dominant climatic factors after PCA screening.

\begin{tabular}{|c|c|c|c|c|}
\hline Main factor & Minimum & Maximum & Mean \pm Standard deviation & $\begin{array}{c}\text { Appropriate distribution region } \\
\text { (Cumulative frequency } \leq 90 \% \text { ) }\end{array}$ \\
\hline Bio $1 /{ }^{\circ} \mathrm{C}$ & 10.90 & 17.40 & $15.31 \pm 0.87$ & $10.90 \sim 16.30$ \\
\hline $\mathrm{Bio} 5 /{ }^{\circ} \mathrm{C}$ & 25.60 & 33.70 & $31.33 \pm 1.17$ & $25.60 \sim 32.40$ \\
\hline $\mathrm{Bio} 11 /{ }^{\circ} \mathrm{C}$ & 0.30 & 6.20 & $3.8 \pm 0.94$ & $0.30 \sim 4.90$ \\
\hline $\mathrm{Bio} 12 / \mathrm{mm}$ & 665.00 & 1875.00 & $1354.24 \pm 328.45$ & $665.00 \sim 1701.00$ \\
\hline $\mathrm{Bio} 14 / \mathrm{mm}$ & 14.00 & 50.00 & $36.6 \pm 11.07$ & $14.00 \sim 47.00$ \\
\hline $\mathrm{Bio} 17 / \mathrm{mm}$ & 45.00 & 188.00 & $135.83 \pm 39.07$ & $45.00 \sim 173.00$ \\
\hline
\end{tabular}



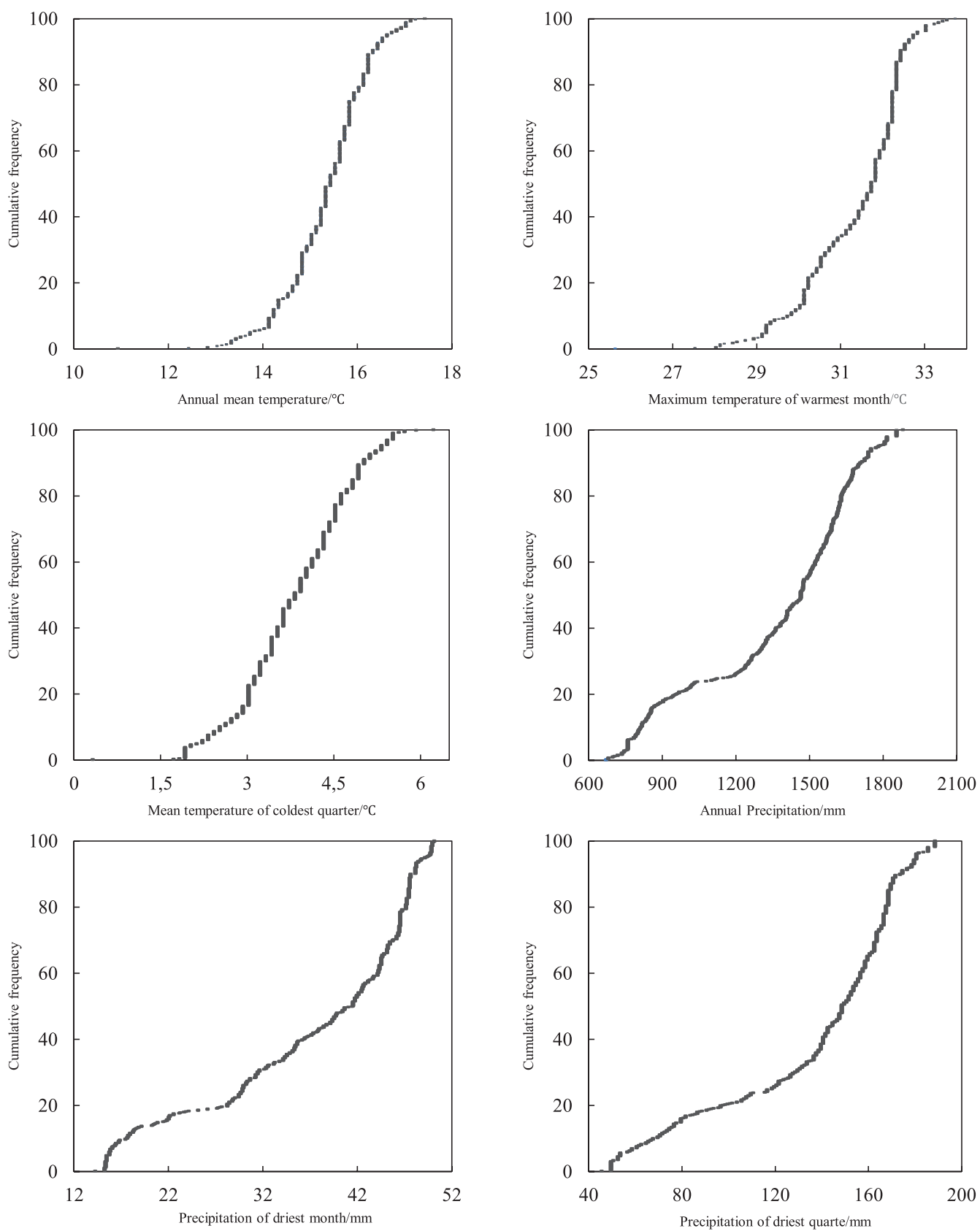

Fig. 3. Cumulative frequency curves of dominant climatic factors.

Fuyang cities. In conclusion, the southeastern and southwestern parts of Anhui Province are the most likely suitable habitats for old trees. Hence, this area should be focused on as a conservation priority area for the cultivation of large and old trees in Anhui Province.

The accuracy of prediction of old trees during the current period was found to be 'excellent' $\left(\mathrm{AUC}_{\text {mean }}=0.969 \pm 0.0416\right.$ ) (Fig. 5). The results showed that the selected bioclimatic variables described the suitable habitat for old trees in Anhui Province very well. A kappa value of 0.921 was calculated, which could be considered to indicate 'very good' agreement between the model and the test data and was consistent with AUC (Fig. 5).

\section{Discussion}

It is of great significance to ensure the accuracy of an SDM. Species distribution is a complex expression of the ecology and evolutionary history of a species, which are controlled by different factors, intensities and spatialtemporal patterns $[61,62]$. Based on the studies of some researchers, the environment, biological characteristics, spread and adaptation of species are the four main factors to determine the distribution patterns of species $[63,64]$. However, the accuracy of prediction models for species distribution patterns was mainly dependent on model performance, species prevalence and sample size $[48,65]$. Generally, the accuracy of the prediction of the ecological characteristics of many rare species would 


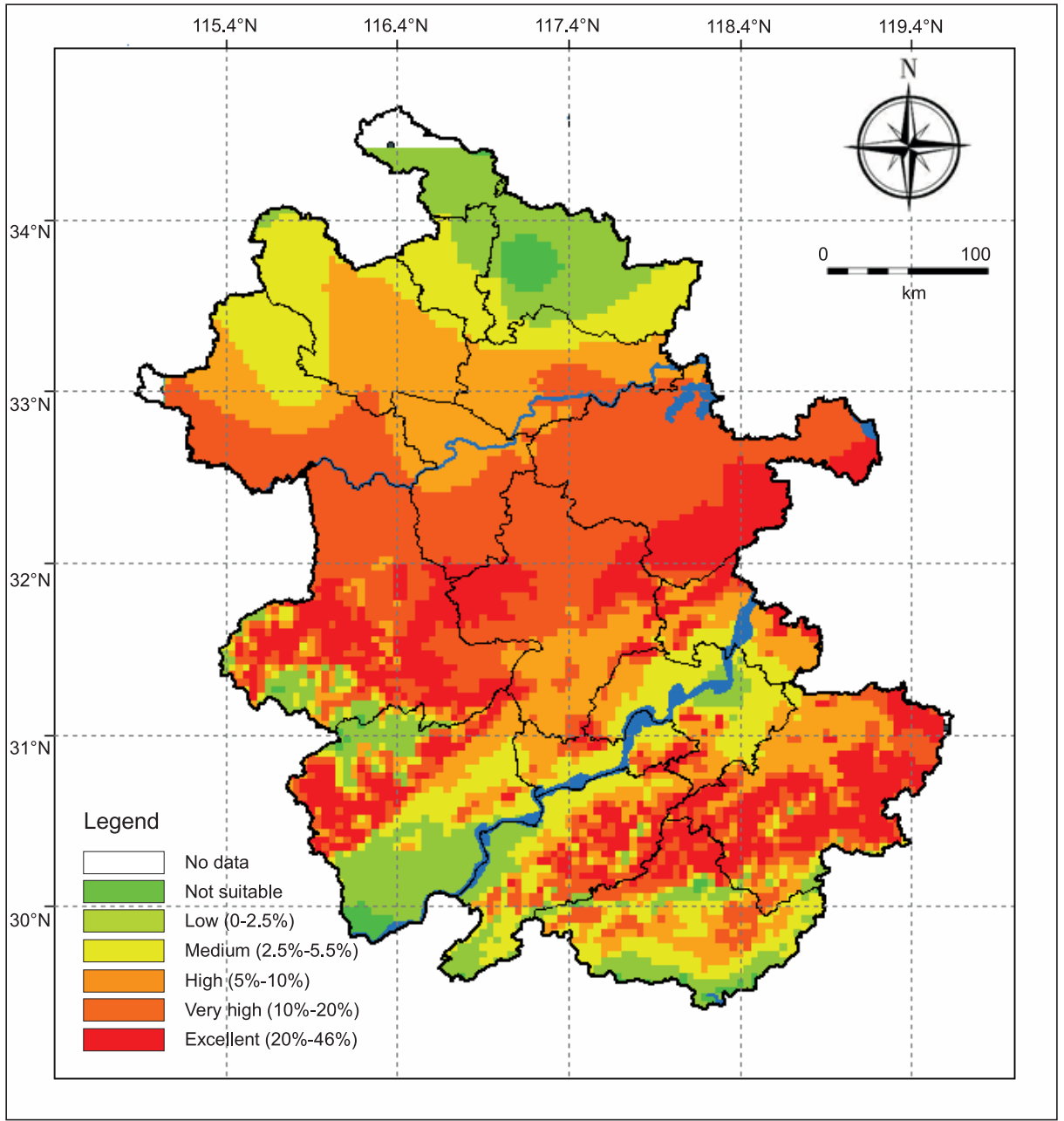

Fig. 4. Modelled suitable distribution pattern of old trees under current climate conditions.

be improved with increasing sample size, especially for species with small geographic ranges and limited environmental tolerance [66]. Many species distribution models have been utilized for prediction [36], but the accuracy of the prediction results could be promoted by appropriate niche models for special studies. BIOCLIM offers a simplistic approach to species distribution modelling [29], which had been one of the most widely used SDM packages and was recognized as one of only three 'well-established modelling methods' [31]. Compared to the other models, BIOCLIM proved to be a highly flexible and powerful tool for evaluating distributions on a variety of spatial scales with limited sample size requirements [29, 67]. According to the 32 natural distribution records, the potential distribution pattern of Cerasus schneideriana was predicted with a high AUC value (0.998) [60]. The BIOCLIM model also performed well in predicting the suitable habitat of some species with a few geographical coordinates, such as Caragana spp. (AUC>0.9) [68], Vitis yunnanensis $(\mathrm{AUC}=0.871) \quad[69]$, Yulania liliiflora $(\mathrm{AUC}=0.998)$ [48], Quercus griffithii (AUC $\approx 0.9$ ) [70], and Fagus sylvatica (AUC = 0.898) [33]. The closer the AUC is to 1 , the better the model performance [71]. According to the customs of nature and humankind, the distribution of old trees was random and uncertain, and these trees required highly suitable habitat; therefore, it was difficult to gather individual samples of old trees. We do not deny the limitation of the BIOCLIM model itself $[29,33]$; however, evaluation by the ROC curve proved that the BIOCLIM distribution model was accurate and reliable in this study (AUC $=0.969$ ). It could be concluded that the simulations had high reliability and could be applied to analyse the suitable habitat for old trees in Anhui Province. This model could be utilized to predict suitable habitats for old trees.

At large temporal and spatial scales, climate is generally regarded as the main determinant of species ranges over broad geographical scales [72]. Researchers always try to determine the most important climatic factor, and PCA is a good method for determining this information. PCA is a multivariate technique that produces a set of abstract variables that are weighted linear combinations of the original variables. The components are constructed to maximize the variance explained by each component and in such a manner that they are uncorrelated (orthogonal) [73]. PCA allows for the identification of climatic conditions governing 

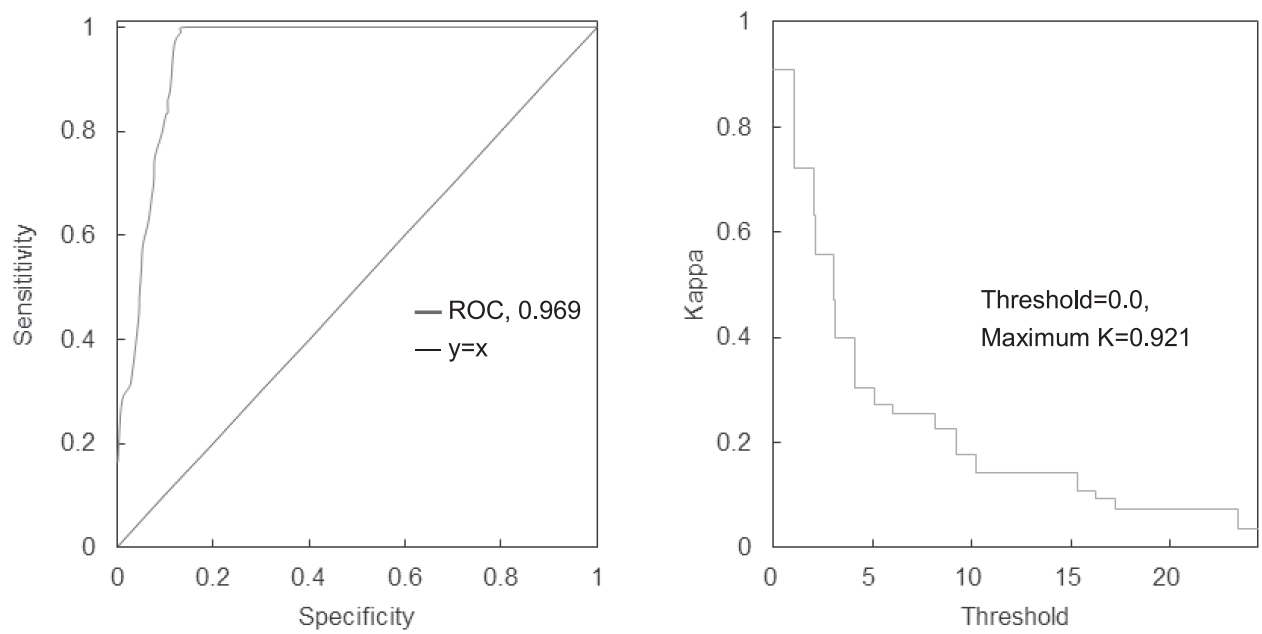

Fig. 5. Results of the AUC and kappa curves of the habitat suitability model.

the distribution of the plant species and permits the comparison of the climatic preferences of all these species. On the basis of PCA, the distributional limits of beech species were primarily associated with thermal factors, and the growing season temperature regime was the most important for illustrating the distribution of Chinese beeches [74]. To predict new occurrences of rare plants in the Rattlesnake Creek Terrane of the Shasta-Trinity National Forest in the northern California Coast Range of the United States, researchers found that $\mathrm{PC} 1$ and $\mathrm{PC} 2$ were strongly correlated with precipitation and elevation, respectively [40]. Such studies based on PCA are efficient in disclosing the main climatic factors governing the distribution patterns of specific species [75-77]. In this paper, PCA was carried out on all 19 climatic parameters, and the results indicated that precipitation had a significant impact on the distribution pattern of old trees in Anhui Province, which will be meaningful for the management of old trees in the future.

Theoretically, 19 bioclimatic variables could be applied to the BIOCLIM model simultaneously to predict the suitable habitat of old trees, but the problem of autocorrelation in the presence data or the multicollinearity of the environmental predictors had to be addressed [35]. Multi-collinearity is a serious statistical problem in non-experimental situations, where the researcher has no control of the risk associated with hypothetical factors related to independent variables [35]. To avoid this problem, the correlation of 19 bioclimatic factors was addressed [36, 78]; for the correlation between two arbitrary factors with an absolute value greater 0.75 , one factor would be chosen; ultimately, the selected factors exhibited low correlation (value of correlation coefficient less than 0.75) [32, 79]. This method required researchers with rich experience. In addition, to reduce autocorrelation, PCA represents the availability of an exact theory to estimate distributions, and the principal components are useful exploratory tools to detect and quantify the mutual relationships among variables [80]. Thus, the predictors of BIOCLIM were universally selected by PCA [47, 48, 60]. Therefore, this method was a preferable way to avoid subjective decisions.

Many studies related to old trees have been carried throughout the world $[4,9,53,81,82]$, but the study scales are limited to small regions, such as woodpasture regions [53, 82], metropolitan areas $[4,81]$, or natural forests within a certain area [9]. These studies mainly focused on the effects of different factors on species diversity, abundance, and spatial patterns of old trees. However, few studies have focused on the climatic influence of old trees on a large spatial scale. The geographic distribution of wild potatoes (Solanaceae sect. Petota) was analysed using a database of 6073 georeferenced observations in America, and they were recorded more often in the Southern Hemisphere at altitudes between 2000 and $4000 \mathrm{~m}$ [51]; thus, this information could be used to assist with cultivation exploitation for raw material and genetic resources in the future. A study on the distribution, diversity and environmental adaptation of highland papayas (Vasconcellea) in tropical and subtropical America provided a better understanding of many other potentially neglected and underutilized species to enhance their conservation and use [75]. These studies include species such as beech (Fagus L.) [74], fir (Abies Mill) [78], and pepper (Piper L.) [39]. We studied the old trees of Anhui Province over a large geographical scale, which referred to many species and an abundance of individuals; this method could predict the suitable habitat for old trees efficiently and provide conservation and management for them scientifically. Therefore, these results are of great significance for the conservation of old trees in the future.

Global warming has been recognized as having an important effect on the natural ecological system and 
life-supporting environment of human beings [83]. The future global extinction risk due to climate change is predicted not only to increase but also to accelerate as global temperatures rise [84], and up to one in six species under the current policies would disappear [85]. Therefore, it is clear that populations of large old trees are rapidly declining in many parts of the world [11] due to the high frequency of extreme climate events $[7,8]$. In this study, the 'excellent' habitat for old trees in Anhui Province was becoming fragmented (Fig. 4). With future climate change, the suitable habitat for old trees will become more fragmented or even disappear. To cope with climate change and minimize disaster consequences, effective conservation management should be proposed. The distribution dynamics and population changes of old trees should be monitored systematically and chronically. At the same time, it is better to build a province-wide conservation database and monitoring network using GIS technology. On this basis, the specific indicators of the impact of climate change on old trees were quantified, and relevant ecological models were established that could effectively predict the temporal-spatial distribution pattern of old trees.

\section{Conclusions}

We must confront the fact that the ongoing decline of old trees had substantial consequences for both biodiversity and the integrity of ecosystems worldwide. There is no time to delay the conservation of old trees. This was the first study to illustrate suitable habitats for old trees in Anhui Province based on the most complete geographical collection dataset compiled thus far. The present study showed that the BIOCLIM model was reasonable and correct according to the evaluation results of the AUC and kappa index. It was obvious that the northern part of Anhui Province was not a suitable area for old trees, but the southeastern and southwestern parts would most likely be suitable for old trees in the future. Among the 19 bioclimatic variables selected by virtue of PCA, the distribution pattern of old trees was mainly influenced by six variables: annual precipitation, precipitation of driest month, precipitation of driest quarter, annual mean temperature, maximum temperature of warmest month, and mean temperature of warmest quarter. We can also conclude that the utilization of GIS with the coordinates of old trees can generate significant value and knowledge of existing information sources, especially for the conservation management of old trees. Furthermore, the administrative department can give priority to the area of 'excellent' habitat predicted by the model, and an indepth investigation should be taken into account in the near future. In this study, bioclimatic variables are only one consideration, but other factors that influence old trees, such as human disturbance, socioeconomic status, soil conditions, and landform, should also be assessed in future study.

\section{Acknowledgements}

This study was supported by the Fundamental Research Funds for the Central Universities (LGZD201907) and the Key Subject Construction Project of Jiangsu Province $13^{\text {th }}$ Five-Year Plan (20162020).

\section{Conflict of Interest}

The authors declare no conflict of interest.

\section{References}

1. MOGA C.I., SAMOILĂ C., ÖLLERER K., BĂNCILĂ R. I., RéTI K.-O., CRAIOVEANU C., POSZET S., RáKOSY L., HARTEL T. Environmental determinants of the old oaks in wood-pastures from a changing traditional social-ecological system of Romania. Ambio. 45 (4), 480, 2016.

2. LINDENMAYER D.B., LAURANCE W.F. The unique challenges of conserving large old trees. Trends Ecol. Evol. 31 (6), 416, 2016.

3. LIU J., LINDENMAYER D.B., YANG W., REN Y., CAMPBELL M.J., WU C., LUO Y., ZHONG L., YU M. Diversity and density patterns of large old trees in China. Sci. Total Environ. 655, 255, 2019.

4. JIM C.Y., ZHANG H. Species diversity and spatial differentiation of old-valuable trees in urban Hong Kong. Urban For. Urban Gree. 12 (2), 171, 2013.

5. MAHMOUD T., GAIROLA S., EL-KEBLAWY A. Large old trees need more conservation attention: A case of Tamarix aphylla in the arid deserts of the United Arab Emirates. J. Asia Pac. Biodivers. 8 (2), 183, 2015.

6. XIE Y., WU H.L., HUANG H.F., LIU J.L., WANG N.L., CAO J., ZHANG Z.M. Ancient trees' health evaluation in Beijing. For. Resour. Manag. 6, 71, 2012.

7. ALLEN C.D., BRESHEARS D.D., MCDOWELL N.G. On underestimation of global vulnerability to tree mortality and forest die-off from hotter drought in the Anthropocene. Ecosphere. 6 (8), 1, 2015.

8. BENNETT A.C., MCDOWELL N.G., ALLEN C.D., ANDERSON-TEIXEIRA K.J. Larger trees suffer most during drought in forests worldwide. Nat. Plants. 1 (10), 15139, 2015.

9. LINDENMAYER D.B., BLANCHARD W., BLAIR D., MCBURNEY L., BANKS S.C. Environmental and human drivers influencing large old tree abundance in Australian wet forests. For. Ecol. Manag. 372, 226, 2016.

10. LINDENMAYER D.B., BANKS S.C., LAURANCE W.F., FRANKLIN J.F., LIKENS G.E. Broad decline of populations of large old trees. Conserv. Lett. 7 (1), 72 , 2014.

11. LINDENMAYER D.B., LAURANCE W.F., FRANKLIN J.F. Global decline in large old trees. Science. 338 (6112), 1305, 2012.

12. CHENG L., LUO P., DENG X.X., LI Z.Q. Study on relationship between ancient and famous trees' growth status and environmental factors: Taking ancient Cinnamomum camphora in Zhejiang province as an example. J. Central South Univ. For. Tech. 35 (11), 86, 2015. 
13. JIM C.Y. Evaluation of heritage trees for conservation and management in Guangzhou City (China). Environmental Management. 33 (1), 74, 2004.

14. JIM C.Y., ZHANG H. Defect-disorder and risk assessment of heritage trees in urban Hong Kong. Urban For. Urban Gree. 12 (4), 585, 2013

15. TIAN L.J., HUANG L., ZHOU L.H., CHEN T.Y., QIAN S.H., YANG Y.C., Yang The composition and distribution of heritage trees in Guizhou ethnic minority areas: A case study of Wuchuan County. Chin. J. Ecol. 37 (9), 2768, 2018.

16. XIAO J.Y., TAN H.F., CHEN J.Y., MIN W.A. Preliminary study on risk assessment model of ancient and famous trees. Hunan For. Sci. Tech. 43 (1), 61, 2016.

17. ZHAO J.H., FENG D.Q., WANG Y.S., GUO S.J., WANG X.Y., ZHAO Y., ZHOU G.F. Study on rejuvenation technique for ancient ginkgo trees. Chin. For. Sci.Tech. 27 (2), 109, 2013.

18. YUAN Y., YE Y.Z., LI Q., XU Y.K., CHEN Z.H., LI L.J. Analysis on causes of decline of ancient and famous trees and its rejuvenation technique. J. Zhejiang For. Sci. Tech. 31 (4), 66, 2011.

19. XIE C.P., HUANG Q., FANG Y., RONG-XUE X.U. Application of image processing technology for identifying the age of old tree. Hubei Agric. Sci. 50 (20), 4289, 2011.

20. JIA H.F., MOU Y.M., DANZENG L.B., LI Y. Age investigation and growth history analysis of old trees in Nyemo County of Tibet, China. J. Appl. Ecol. 29 (7), 2401, 2018.

21. WANG B.Y., XIU X.T., LAN S.R. Monetary valuation of the cultural value of ancient and famous trees. Issues For. Econ. 36 (6), 565, 2016.

22. YANG Y., TIAN M.H., WEI Q.G., ZHANG Z.Y., LI C.H. Monetization evaluation on the comprehensive value of old and valuable trees in cities-A case study of "Marguis of Shade" in Beijing. J. Arid Land Resour. Environ. 33 (6), 185, 2019.

23. WEN X.R., ZHOU C.G., HAI-BING X.U., LIU S.W., WAN Z.Z. Application of ComGIS on geographical information system for ancient and famous trees. Journal of Fujian Forestry Science \& Technology. 33 (4), 73, 2006.

24. WANG J.J., TANG L.Y., DING L., LIN Y.X. Design and realization of $3 \mathrm{D}$ management information system for ancient and famous trees based on virtual plant. Chin. For. Sci. \& Tech. 16 (3), 66, 2012

25. WU D.H., WANG Y.X., SUN Z.H. Design and development of ancient and well-known tree patrol application based on GIS. For. Resour. Manag. 3, 141, 2018.

26. MENG X.J., YANG Y.Q., YONG-CHANG Y.E., LIU S.S., SHEN D.C. The design and development of dongguang old and famous trees geographic information system. J. South China Agric. Univ. 30 (1), 104, 2009.

27. GAO Y., BRANCH K. Present situation and protection countermeasures of ancient and famous trees in Chengjiang County. For. Invent. Plan. 42 (2), 117, 2017.

28. YI Q.F., WANG F.G., YE Q.J., LIU D.M., CHEN H.F., XING F. W. Preliminary report on investigation of ancient and famous trees in Conghua City of Guangzhou. J. Plant Resour. Environ. 20 (1), 69, 2011.

29. BOOTH T.H., NIX H.A., BUSBY J.R., HUTCHINSON M.F. BIOCLIM: the first species distribution modelling package, its early applications and relevance to most current MAXENT studies. Divers. Distrib. 20 (1), 1, 2014.

30. DYDERSKI M.K., PAŹ S., FRELICH L.E., JAGODZIŃSKI A.M. How much does climate change threaten European forest tree species distributions? Global Change Biol. 24 (3), 1150, 2018.

31. ELITH J., H. GRAHAM C., P. ANDERSON R., DUDíK M., FERRIER S., GUISAN A., J. HIJMANS R., HUETTMANN F., R. LEATHWICK J., LEHMANN A. Novel methods improve prediction of species' distributions from occurrence data. Ecography. 29 (2), 129, 2006.

32. PEARSON R.G., RAXWORTHY C.J., NAKAMURA M., PETERSON A.T. Predicting species distributions from small numbers of occurrence records: a test case using cryptic geckos in Madagascar. J. Biogeogr. 34 (1), 102, 2007.

33. RASZTOVITS E., MÓRICZ N., BERKI I., PÖTZELSBERGER E., MÁTYÁS C. Evaluating the performance of stochastic distribution models for European beech at low-elevation xeric limits. Időjárás. 116 (3), 173, 2012.

34. JARYAN V., DATTA A., UNIYAL S.K., KUMAR A., GUPTA R.C., SINGH R.D. Modelling potential distribution of Sapium sebiferum - an invasive tree species in western Himalaya. Curr. Sci. 105 (9), 1282, 2013.

35. CRUZ-CÁRDENAS G., LÓPEZ-MATA L., VILLASEÑOR J.L., ORTIZ E. Potential species distribution modeling and the use of principal component analysis as predictor variables. Rev. Mex. Biodivers. 85 (1), 189, 2014.

36. BUCKLIN D.N., BASILLE M., BENSCOTER A.M., BRANDT L.A., MAZZOTTI F.J., ROMANACH S.S., SPEROTERRA C., WATLING J.I. Comparing species distribution models constructed with different subsets of environmental predictors. Divers. Distrib. 21 (1), 23, 2015.

37. WEI B., WANG R., HOU K., WANG X., WU W.J.G. E., CONSERVATION. Predicting the current and future cultivation regions of Carthamus tinctorius L. using MaxEnt model under climate change in China. Glob. Ecol. Conserv. 16, e00477, 2018.

38. BARBOSA F.G., SCHNECK F. Characteristics of the top-cited papers in species distribution predictive models. Ecol. Model. 313, 77, 2015.

39. PARTHASARATHY U., GEORGE J., SAJI K.V., SRINIVASAN V., MADAN M.S., MATHUR P.N., PARTHASARATHY V.A. Spatial analysis for Piper species distribution in India. Plant Genet. Resour. Newsl. 147, 1, 2006.

40. WILLIAMS J.N., CHANGWAN S., THORNE J., NELSON J.K., ERWIN S., O'BRIEN J.M., SCHWARTZ M.W. Using species distribution models to predict new occurrences for rare plants. Divers. Distrib. 15 (4), 565, 2009.

41. SPIERS J.A., OATHAM M.P., ROSTANT L.V., FARRELL A.D. Applying species distribution modelling to improving conservation based decisions: a gap analysis of Trinidad and Tobago's endemic vascular plants. Biodivers. Conserv. 27 (11), 2931, 2018.

42. AHMED S.E., MCINERNY G., O'HARA K., HARPER R., SALIDO L., EMMOTT S., JOPPA L.N. Scientists and software - surveying the species distribution modelling community. Divers. Distrib. 21 (3), 258, 2015.

43. HIJMANS R.J., GUARINO L., CRUZ M., ROJAS E. Computer tools for spatial analysis of plant genetic resources data: 1. DIVA-GIS. Plant Genet. Resour. Newsl. 127, 15, 2001.

44. SUNIL N., SIVARAJ N., ANITHA K., ABRAHAM B., KUMAR V., SUDHIR E., VANAJA M., VARAPRASAD K. S. Analysis of diversity and distribution of Jatropha curcas L. germplasm using Geographic Information 
System (DIVA-GIS). Genet. Resour. Crop Evol. 56 (1), 115, 2009.

45. SEMWAL D., BHANDARI D., BHATT K., SINGH R. Diversity distribution pattern in collected germplasm of rapeseed-mustard using GIS in India. India J. Plant Genet. Resour. 26 (1), 76, 2013.

46. DAR Z., LONE A., SUNIL N., SIVARAJ N., ZAFAR G., MAKDOOMI M., GAZAL A., ELAHI B., ALI G., HABIB M. Diversity analysis of maize inbred lines using DIVA-GIS under temperate ecologies. J. Appl. Nat. Sci. 8 (3), 1576, 2016.

47. QIU J., ZHU H., CHEN X., TANG G. Modeling the suitable areas and ecological characteristics of Sorbus alnifolia using DIVA-GIS software. J. Beijing For. Univ. 40 (9), 25, 2018.

48. SUN L.Y., JIANG Z., LIU C.N., YIN Z.F. Analysis of the adaptive and geographical distribution of Yulania liliiflora based on DIVA-GIS. Plant Sci. J. 36 (6), 804, 2018.

49. CHAND D., DIKSHIT N., SIVARAJ N., GOMASHE S., NIZAR M. Diversity assessment in Abelmoschus tuberculatus: A DIVA-GIS study. J. Environ. Biol. 39(4), 426, 2018.

50. WAGNER M., TRUTSCHNIG W., BATHKE A.C., RUPRECHT U. A first approach to calculate BIOCLIM variables and climate zones for Antarctica. Theor. Appl. Climatol. 131 (3-4), 1397, 2018.

51. HIJMANS R.J., SPOONER D.M. Geographic distribution of wild potato species. Am. J. Bot. 88 (11), 2101, 2001.

52. LINDENMAYER D.B., LAURANCE W.F. The ecology, distribution, conservation and management of large old trees. Biol. Rev. 92 (3), 1434, 2017.

53. HARTEL T., RÉTI K.O., CRAIOVEANU C. Valuing scattered trees from wood-pastures by farmers in a traditional rural region of Eastern Europe. Agric., Ecosyst. Environ. 236, 304, 2017.

54. SCIPIONI M.C., DOBNER JR M., LONGHI S.J., VIBRANS A.C., SCHNEIDER P.R. The last giant Araucaria trees in southern Brazil. Sci. Agr. 76 (3), 220, 2019.

55. HAMMER Ø., HARPER D.A., RYAN P.D. PAST: paleontological statistics software package for education and data analysis. Palaeontol. Electron. 4 (1), 9, 2001.

56. FAWCETT T. An introduction to ROC analysis. Pattern Recog. Lett. 27 (8), 861, 2006.

57. SWETS J.A. Measuring the accuracy of diagnostic systems. Science. 240 (4857), 1285, 1988.

58. ALLOUCHE O., TSOAR A., KADMON R. Assessing the accuracy of species distribution models: prevalence, kappa and the true skill statistic (TSS). J. Appl. Ecol. 43 (6), 1223, 2006.

59. ZHANG X.W., LI Y., FANG Y.M. Geographical distribution and prediction of potential ranges of Quercus acutissima in China. Acta Botanica Boreali-Occidentalia Sinica 34 (8), 1685, 2014.

60. ZHU H., YOU L.X., LI Y.F., WANG H.C., WANG X.R. Modeling the geographical distribution pattern and climatic limited factors of Cerasus schneideriana. J. Trop. Subtrop. Bot. 25 (4), 315, 2017.

61. YI Y.J., CHENG X., YANG Z. F., ZHANG S.H. Maxent modeling for predicting the potential distribution of endangered medicinal plant (H. riparia Lour) in Yunnan, China. Ecol. Eng. 92, 260, 2016.

62. FRANKLIN J., JENNIFER A.M. Mapping species distributions: spatial inference and prediction. Cambridge, UK: Cambridge University Press; 2009.
63. SOBERÓN J., NAKAMURA M. Niches and distributional areas: concepts, methods, and assumptions. Proc. Natl. Acad. Sci. 106 (Supplement 2), 19644, 2009.

64. SOBERÓN J.M. Niche and area of distribution modeling: a population ecology perspective. Ecography. 33 (1), 159, 2010.

65. PROOSDIJ A.S.J.V., SOSEF M.S.M., WIERINGA J.J., RAES N. Minimum required number of specimen records to develop accurate species distribution models. Ecography. 39 (6), 542, 2016.

66. HERNANDEZ P.A., GRAHAM C.H., MASTER L.L., ALBERT D.L. The effect of sample size and species characteristics on performance of different species distribution modeling methods. Ecography. 29 (5), 773, 2006.

67. BOOTH T.H., JOVANOVIC T. Climatology of acacia mearnsii. 1. characteristics of natural sites and exotic plantations. New Forests. 2 (1), 17, 1988.

68. WANG J. Modelling the distribution of five Caragana species in temperate northern China. Chinese Journal of Plant Ecology. 33 (1), 12, 2009.

69. JIANG J.F., FAN X.C., ZHANG Y., WEI W., KANG D.M., LIU C.H. Modeling the geographic distribution of three endangered Vitis species in China. Chin. J. Ecol. 33 (6), 1615, 2014.

70. SHAO H., TIAN J.Q., GUO K., SUN J.X. Effects of sample size and species traits on performance of bioclim in predicting geographical distribution of tree species-a case study with 12 deciduous Quercus species indigenous to China. J. Plant Ecol. 33 (5), 870, 2009.

71. LI G.Q., LIU C.C., LIU Y.G., YANG J., ZHANG X.S., GUO K. Advances in theoretical issues of species distribution models. Acta Ecologica Sinica. 33 (16), 4827, 2013.

72. NORMAND S., RICKLEFS R.E., SKOV F., BLADT J., TACKENBERG O., SVENNING J.-C. Postglacial migration supplements climate in determining plant species ranges in Europe. Proc. Royal Soc. B. 278 (1725), 3644, 2011.

73. ROBERTSON M.P., CAITHNESS N., VILLET M.H. A PCA-based modelling technique for predicting environmental suitability for organisms from presence records. Divers. Distrib. 7 (1-2), 15, 2001.

74. FANG J., LECHOWICZ M.J. Climatic limits for the present distribution of beech (Fagus L.) species in the world. J. Biogeogr. 33 (10), 1804, 2006.

75. SCHELDEMAN X., WILLEMEN L., D'EECKENBRUGGE G.C., ROMEIJN-PEETERS E., RESTREPO M.T., MOTOCHE J.R., JIMÉNEZ D., LOBO M., MEDINA C., REYES C. Distribution, diversity and environmental adaptation of highland papayas (Vasconcellea spp.) in tropical and subtropical America. In: Plant Conservation and Biodiversity: Springer; 2006: 293.

76. LI M., YI X.G., WANG H.C., SHANG T., GU Y., WANG X.R. Studies on the relationship between Cerasus serrulata distribution region and the environmental factors. J. Nanjing For. Univ. 38 (9), 74, 2014.

77. RAES N., ROOS M.C., SLIK J.W.F., LOON E.E.V., STEEGE H.T. Botanical richness and endemicity patterns of Borneo derived from species distribution models. Ecography. 32 (1), 180, 2009.

78. LIU R., WANG C.J., JIAN H.E., ZHANG Z.X. Analysis of geographical distribution of Abies in China under climate change. Bulletin of Botanical Research. 38 (1), 37, 2018. 
79. GRAHAM M.H. Confronting multicollinearity in ecological multiple regression. Ecology. 84 (11), 2809, 2003.

80. ZHANG J.T. Quantitative Ecology. Beijing: Science Press; 2011.

81. ZHANG H., LAI P.Y., JIM C.Y. Species diversity and spatial pattern of old and precious trees in Macau. Landscape Urban Plann. 162, 56, 2017.

82. HARTEL T., HANSPACH J., MOGA C.I., HOLBAN L., SZAPANYOS Á., TAMÁS R., HOVÁTH C., RÉTI K.-O. Abundance of large old trees in wood-pastures of
Transylvania (Romania). Sci. Total Environ. 613, 263, 2018.

83. ROOT T.L., PRICE J.T., HALL K.R., SCHNEIDER S.H., ROSENZWEIG C., POUNDS J.A. Fingerprints of global warming on wild animals and plants. Nature. 421 (6918), 57, 2003.

84. URBAN M.C. Accelerating extinction risk from climate change. Science. 348 (6234), 571, 2015.

85. WIENS J.J. Climate-related local extinctions are already widespread among plant and animal species. PLoS Biol. 14 (12), e2001104, 2016. 
